\title{
NARRATIVE ANALYSIS OF THE KURDISH PERSONAL NARRATIVES
}

\author{
Hallat RAJAB EBRAHim \\ Dept. of English, College of Languages, University of Duhok, Kurdistan Region-Iraq
}

(Received: January 21, 2020; Accepted for Publication: May 13, 2020)

\begin{abstract}
This study investigates the similarities and difference between the English and Kurdish conversational stories told by Iraqi Kurdish bilingual speakers. Through the quantitative and qualitative analysis of the data (20 hours audio-taped conversational stories told by five Kurdish bilingual speakers in Kurdish and English), the self representation of the Kurdish speakers was examined through emphasizing the ways in which the moral stance dimensions of the personal narratives are enacted in the Kurdish conversational stories by using Labov (1972) and Ochs and Capps's (2001) models of narrative analysis. The quantitative analysis demonstrates that the Kurdish narrators almost use the same range of the evaluative devices in both the Kurdish and English stories, but that they employ these with a varying extent. This variation has provided the start point to identify the moral positioning by Kurdish bilingual speakers. The moral positioning in this study prompts a range of distancing between the protagonists. The distancing identified was Kurdish-Arabic. This indicated the racial tension between Kurds and Arabs, nominating the Kurdish ethnic identity.
\end{abstract}

KEYWORDS: Conversational stories, Narrative analysis, Moral stance, Moral positioning

\section{INTRODUCTION}

T his cross-cultural study investigates the similarities and differences of Kurdish self- representation in the conversational stories told by Iraqi Kurdish bilingual speakers in Kurdish and in English. Particular attention is given to Labov (1972) and Ochs and Capps's (2001) models of evaluation. Both Labov's and Ochs and Capps's approaches have strengths and weaknesses. Rooted in the structural tradition, Labov's (1972) model of evaluation sets out a series of categories which are distinguished on the basis of grammatical features. The focus on grammatical features is a strength because it appears less subjective and a tractable means to identify the features which in turn point to narrative structure. However, the lack of contextual variation and interaction is the source of this model's weakness. As post-Labovian researchers such as (De Fina and Georgakopoulou, 2008, Norrick, 2000 and Georgakopoulou, 2007) have pointed out; Labov's model has a productivist-structuralist emphasis. These researchers have expanded Labov's idea by emphasizing how narratives are co-constructed by narrators and audiences in different contexts. For example, Polanyi's (1985) study of American story telling underscores the significance of cultural variation in assigning the tellability of a story. Sacks (1992) and
Georgakopoulou (2005) emphasised the occurrence of the interactional features produced by both the speaker and the listener) in the opening of the story (the preface) in order to inform the listeners of the point of the story, and in turn prepare them for offering appropriate contributions to the story events. Sunakawa (2010) argued that features like laughter, and reported speech marked by a shift in prosody, were also found in the story structure. Also Georgakopoulou's (2007) work highlights the interactional features of small stories (non canonical stories) collected in various contexts. In her longitudinal study, Georgakapolou conducted an ethnographic methodology to analyze the stories or the casual talk that took place among some girls who were living in the same place. These girls were friends and were meeting in cafes and restaurants and shared their every day stories

On the other hand, Ochs and Capps's (2001) model focuses on "attitudes to language, dialect production, perception, and use, and particularly on attitudes to language variation, dialect, speech style, language preference, and minority languages as well as their speakers" (Garrett, etal.2003: p.467). Ochs and Capps' work is more oriented to narration as process. Their approach is more context-sensitive and points to the wide variation that is found in narrative form and function. Although they do not mention 
evaluation specifically, it is implicit in many of their narrative dimensions (particularly tellability and moral stance). Their attentiveness to context and interaction moving away from narrative structural alone is a strength, but on the other hand, the subjectivity of how the narrative dimensions are interpreted reveals their model's weakness.

Labov's (1972) structural model of evaluation and Ochs and Capps's (2001) dimensions of narrative are complementary (Page, 2002) to each other and in this study they will be integrated (as Page did in her analysis of the child birth narratives) in order to see how far the categories identified by Labov (1972) can point towards the moral stance of the speakers of the present data. According to Ochs and Capps (2001) moral stance is the part of personal narrative which has the main purpose of 'holding people accountable for their conduct' (p. 105). Narrative underscores morality since the narrated events usually take 'unexpected turns' and are assessed through moral stance as good or bad, accepted or rejected, common or uncommon in a society (Ochs \& Capps, 2001: 173). To analyze self-representation of the Kurdish speakers, emphasis will be placed on the ways in which the moral dimensions of personal narratives are enacted in the Kurdish conversational stories which tell of ethnic conflicts. These Kurdish speakers met verbal ethnic challenges with Arab teachers, employers and patients ((Hamo andAbdullah, 2014; Balatay, 2014). In this study, the focus will be on the enactment of moral stance through Labov's (1972) grammatical evaluative devices, especially those related to reported speech. The rationale for choosing Labov's grammatical devices in this study is due to two reasons. First, the data collected for the present study evident different types of these devices. Second, Labov's grammatical devices were long used by many researchers as useful tools to explore the speakers' identities and self representations like Peterson and McCabe (1983), Cortazzi and Jin (1999), Johnstone (2001), Klapproth (2004), Smith (2006), Patterson (2008), Chang (2008), Mason (2008) and many more.

\section{REPORTED SPEECH}

The act of transmitting others' and one self's utterances is called reported speech (Voloshinov, 1973). Reported speech is interpreted as "the reflexive capacity of language to report utterances, index and describe aspects of the speech event, and guide listeners in the proper interaction of their utterances" (Lucy, 1993: 11). Reported speech also has been related to evaluation or assessment which displays the reporters' positioning towards the reported speech (Buttny, 1997; O'Connor, 1997 cited in Pastor and Maria, 2004: 93) and therefore performing different functions as 'to dramatize a point, to give evidence for a position or to epitomize a condition' (ibid:478). Reported speech as an evaluative device was first proposed by Labov and Waltezky (1967) and then Labov (1972) as embedded evaluation. According to Labov (1972) this type of evaluation does not suspend the action of the narrative rather its establishment in the narrative retains the dramatization of the events. Labov (1972: 372-373) suggests three steps in embedding evaluation into narrative:

The first step is..... for the narrator to quote the sentiment as something occurring to him at the moment rather than addressing it to the listener outside of the narrative.......... A second step towards embedding evaluation is for the narrator to quote himself as addressing someone else...... The next step inward is to introduce a third person who evaluates the antagonist's actions for the narrator.

The types of embedded evaluation mentioned in the quote above will be addressed in the analysis of the current study.

Researchers like Wanger etal (2014), Oliveira and Cunha (2004) have shown the relationship between reported speech and other forms of evaluation such as prosodic devices and voice quality. Prosodic devices include 'different auditory aspects of speech such as loudness, duration, pitch, and pause' (Couper-Kuhlen, 1986: 4), whereas voice quality includes 'paralinguistic cues which a speaker may tentatively use to produce a whispery, breathy, falsetto, aspirated voice and etc' (ibid: 3 ). The prosodic devices along with voice quality are adopted by speakers which in part can contribute to the evaluative potential of a quoted utterance (ibid). Furthermore, in his analysis of every day reported speech, Güthner (1999: 704) has pointed out that speakers use prosodic devices together with voice quality to 'animate' the reported characters and distinguish between them, and to reveal the narrator's stance and comments towards the reported events. Moreover, Levey (2003) maintains that the prosodic device in quoted dialogues 'not only 
facilitates the re-enactment of a past personal drama, but also enables reporting speakers to contextualize their own attitudinal alignment towards the reported dialogue' (p. 311). Thus the correlation evident among these evaluative devices (quoted speech, prosodic devices and voice quality) would 'animate' (Güthner, 1999: 704) the reported events and characters on the one hand, and dramatize, give voice to the narrators' sentiments, and stances towards them on the other hand.

\section{DATA AND METHODOLOGY}

The data of the current study comprises five hours of audio-taped conversational stories of different length. The researcher was a participant-observer in the process of data collection. Permission to tape record the participants' conversational stories was ensured beforehand and the tape recorder was put visible to all the participants. The recording took place at the School of Humanities College of Arts building where the participants worked. Particularly, most of the meetings had taken place in the school of humanities staff café and few of them in the college library. All the recordings were undertaken during the participants' leisure times.

The participants of this study are five bilingual graduate students whose first language is Kurdish, English being their second language. They are graduates from the University of Duhok/ school of Humanities/College of Arts/ Department of English. Their ages ranged between 23-26 years old. All were friends, and were working at school of Humanities/College of Arts/ University of Duhok. Moreover, before commencing recording, the participants' acceptance to take part in the process of data collection was ensured by signing a consent form. In the transcriptions, all the personal information about the participants was anonymized. Each was given a pseudonymous name. The participants were asked once during the whole period of data collection to recite their life and personal experiences without selecting any specific topic to recount or discuss.

\section{OVERVIEW OF LABOVIAN ANALYSIS: QUANTITATIVE RESULTS}

The analysis begins with a quantitative comparison of Labov's (1972) subtypes of evaluation. The first point of comparison is between the occurrences of external evaluation. Within this category, three different forms are distinguished. In the first form, the narrator addresses the listeners directly, by which the narrative action is stopped by the speaker to tell its point (Labov, 1972). This subtype of evaluation is referred to by Toolan (1988) as 'wholly external evaluation - as external as you can get' (p. 156). The second subtype of external evaluation occurs when the narrator addresses herself/ himself where the narrative is not suspended and the third subtype of external evaluation is evaluation action in which others' actions are conveyed rather than their speech. These subtypes of external evaluation are considered as relevant to the present study mainly because of their evaluative functions which might point towards the moral stances that the narrators want to take.

Based on the quantitative analysis of this material in Table 1, it can be seen that the first subtype, where the narrator is addressing the listener directly, is the only external evaluative device used in the stories told in Kurdish $(1.06 \%)$. The Kurdish stories did not contain any instances of the second subtype, where the narrator is addressing himself. Furthermore, the third subtype (the evaluation action) did not occur in the Kurdish stories. However, it is noted that the stories told in English contain (1.12\%) instances of the first subtype and a very slight occurrence of the second subtype $(0.03 \%)$ is identified.

In general, the results demonstrate no marked differences in the use of external evaluation in the stories told in Kurdish and in English. However, Kurdish narrators tend to address the listeners directly (first subtype) in the stories told in Kurdish slightly less than they do in the stories told in English (1.06\%) and (1.12\%) respectively. Although the Kurdish narrators have used the second subtype very slightly $(0.03 \%)$ in the stories told in English, they have not done so in the stories told in Kurdish. Also it is evident from the results that Kurdish narrators have neither used the evaluation of the action (third subtype) in the stories told in Kurdish nor in the stories told in English. 
Table (1): The Frequency of External Evaluation subtypes

\begin{tabular}{|c|c|c|c|}
\hline Subtype & $\begin{array}{l}1^{\text {st }} \text { type } \\
\text { Addressing the listeners } \\
\text { directly }\end{array}$ & $\begin{array}{l}2^{\text {nd }} \text { type } \\
\text { Addressing the narrator } \\
\text { herself/himself }\end{array}$ & $\begin{array}{l}3^{\text {rd }} \text { type } \\
\text { The evaluation action } \\
\text { when the narrator tells } \\
\text { what people did rather } \\
\text { than what they said }\end{array}$ \\
\hline $\begin{array}{l}\text { Examples from stories } \\
\text { told in Kurdish by } \\
\text { Kurdish speakers }\end{array}$ & $\begin{array}{l}\text { Ye resh bu gelek ke kret } \\
\text { bu. } \\
\text { Translation: } \\
\text { It was black and very } \\
\text { ugly. }\end{array}$ & & \\
\hline Frequency & $1.06 \%$ & $0 \%$ & $0 \%$ \\
\hline $\begin{array}{l}\text { Examples from stories } \\
\text { told in English by } \\
\text { Kurdish speakers }\end{array}$ & They are so racist. & $\begin{array}{l}\text { said I I I I told myself,"it } \\
\text { seems that this works, it } \\
\text { seems that we can gain } \\
\text { something". }\end{array}$ & \\
\hline Frequency & $1.12 \%$ & $0.03 \%$ & $0 \%$ \\
\hline
\end{tabular}

The frequency of embedded evaluation in the stories told in Kurdish and in English is rather different and is summarized in Table 2.

Table (2): The frequency of Embedded Evaluation subtypes

\begin{tabular}{|c|c|c|c|}
\hline Subtype & $\begin{array}{l}1^{\text {st }} \text { type } \\
\text { The narrator quoting the } \\
\text { sentiment as occurring } \\
\text { to herself/himself at the } \\
\text { moment }\end{array}$ & $\begin{array}{l}2^{\text {nd }} \text { type } \\
\text { The narrator quoting } \\
\text { herself/himself } \\
\text { addressing someone } \\
\text { else }\end{array}$ & $\begin{array}{l}3^{\text {rd }} \text { type } \\
\text { The narrator introduces } \\
\text { a third person to } \\
\text { evaluate the event }\end{array}$ \\
\hline $\begin{array}{l}\text { Examples from stories } \\
\text { told in Kurdish by } \\
\text { Kurdish speakers }\end{array}$ & & $\begin{array}{l}\text { Hndi:::mn gut,'Bes defmn } \\
\text { ben ez dzanm ye } \\
\text { Ikeye,bes eza zhe } \\
\text { dtrsmn'. } \\
\text { Translation: } \\
\text { I kept::: telling him, 'move } \\
\text { it from my desk because I } \\
\text { am scared'. }\end{array}$ & $\begin{array}{l}\text { Veja gute, 'diyare nesaxiye } \\
\text { tesir ye Itekri'. } \\
\text { Translation: } \\
\text { And he told him,' it seems } \\
\text { your sickness had affected } \\
\text { you'. }\end{array}$ \\
\hline Frequency & $0 \%$ & $0.35 \%$ & $1.42 \%$ \\
\hline $\begin{array}{l}\text { Examples from stories } \\
\text { told in English by } \\
\text { Kurdish speakers }\end{array}$ & said," & $\begin{array}{l}\text { said li } \\
\text { I said, I I told him, "no } \\
\text { you are coming". }\end{array}$ & $\begin{array}{l}\text { He told me 'no you should } \\
\text { not do this, it is not the } \\
\text { way you respect teachers'. }\end{array}$ \\
\hline Frequency & $0 \%$ & $0.61 \%$ & $1.53 \%$ \\
\hline
\end{tabular}

Based on the quantitative comparison of the subtypes of embedded evaluation, there are two key observations to be made. First the most frequent type of embedded evaluation in the stories told in Kurdish is the third subtype $(1.42 \%)$, where the narrator introduces a third person to evaluate the event. In the stories told in Kurdish, this type occurred the most four times more often than the narrators presenting themselves as speakers $(0.35 \%)$. This pattern was also true for the stories told in English. But as these figures suggest, the narrators favor embedded evaluation more when they tell stories in English $(0.61 \%$ and $1.53 \%)$ than in Kurdish $(0.35 \%$ and $1.42 \%)$.

A pattern of difference can also be observed when the types of internal evaluation are quantified. Both the stories told in Kurdish and in English used a range of internal evaluation devices. The internal evaluative devices are classified as follows: 
1. Intensifiers (Examples from stories told in $\underline{\text { Kurdish) }}$

a. Expressive Phonology:

Ez w Dlxush yet su:::r buyn.

Translation

Dilxush and I got re:::d.

b. Exaggerated Quantifiers:

Bawerbke nem kushtiya ewa chende.

Translation

Believe me I did not kill any insect since then.

c. Lexical Items:

Ch dit qafkak bu galak ye janbu.

Translation

She found a very beautiful vase.

\section{d Repetition:}

E keke tube man krd tube.

Translation

I have repented-repented.

Intensifiers ( Examples from stories told in English)

a. Expressive Phonology:

He was r:::eally angry again.

b. Exaggerated Quantifiers:

We all come to her house, and try to calm down her.

c. Lexical Items:

And I was really happy.

d. Repetition:

I was among= among Arabs that(.) time.

\section{Comparators (Examples from stories told} in Kurdish)

a. Imperatives:

W gute, 'de pichek ve drky paqzh ken'.

Translation

And told them 'clean this place'.

b. Questions:

W guti 'Ewch xebseye?'

Translation

And said, 'what is this noise?'

c. Negatives:

Nza hema xushe.

Translation

I do not know. It is nice.

d. Futures:

Zhxalawiva gute de saretebrm.

$\underline{\text { Translation }}$
He thought that she told him that she will cut his head.

\section{e. Modals:}

Guti, 'de bain danine ber pet st Lola'.

Translation

He said, 'we will put it under Mis Lola's feet to scare her'.

\section{Comparators: (Examples from stories told in}

English)

a. Imperatives:

You Kurds are like that.

b. Questions:

'What is wrong with me?'

c. Negatives:

You are/ you do not know anything.

d. Futures:

'I am not going to the party'.

\section{e. Modals:}

You should have returned home.

f. Quasi Modals:

I did not use to complain to my mom even once.

g. Comparatives:

That scene was bigger than me.

3. Correlatives: ( Examples from stories told in English)

a. Be...ing:

while I was writing I said......

b. Double ing:

Well I am doing and doing well.

c. Double Attributive:

I saw a tall ugly thin man knocking ding-dingding at the door.

\section{Explicatives (Examples from stories told in} English)

a. Simple: qual:

While I was writing I said...

b. Simple: caus:

A woman had got into hell because she tortured a cat.

c. Complex: caus: 
And I like there because I want sit there because it was at that side was too far because my eyes are .... I have glasses.

\section{d. Compound: caus:}

You cannot express your idea or give her the answers because we are the students were afraid that she will mock at them.
The internal evaluative devices in both the Kurdish and English stories are quantified in Table 3 below:

Table (3): The overall frequency of the main categories of Internal Evaluative devices

\begin{tabular}{lll}
\hline & Stories told in Kurdish & $\begin{array}{l}\text { Stories told in English by Kurdish } \\
\text { speakers }\end{array}$ \\
\hline Intensifiers & $3.01 \%$ & $4.89 \%$ \\
\hline Comparators & $2.91 \%$ & $4.26 \%$ \\
\hline Correlatives & $0 \%$ & $0.6 \%$ \\
\hline Explicatives & $0 \%$ & $0.47 \%$ \\
\hline
\end{tabular}

The findings in Table 3 suggest that the most frequent type of internal evaluation is intensifiers, shortly followed by comparators. These types dominated both stories told in Kurdish and in English, but were slightly more frequent in the stories told in English. Correlative and explicatives are relatively rare. They did not occur at all in the stories told in Kurdish, and occurred much less than intensifiers and comparators in the stories told in English. This variation in the use of evaluative devices could be due to the type of the stories they recounted in Kurdish and in English.

Overall, the quantitative analysis demonstrates that the narrators use almost the same range of evaluative devices in both the Kurdish and English stories, but that they employ these to a varying extent. This suggests that Labov's (1972) evaluative devices are quite transferable and occur in different language types that have not been analysed from this perspective before (in this case, the Kurdish dialects). However, the varying frequency of these evaluative subtypes suggests that there are different performative modes when bilingual speakers employ different languages. We might then question why speakers might elect different performative modes and what these choices might mean. It has been noticed that the types of intensifiers and comparators in the data considered in this study tended to co-occur with instances of direct reported speech differently in the stories told in Kurdish and in English. This in turn suggests that the events are dramatized differently in the stories told in Kurdish and in English. To find out more about these differences, an analysis of the direct reported speech as occurred in the data of the present study is fully developed in the next section.

\subsection{Reported Speech as an Evaluative Device}

The instances of reported speech found in the narratives told by bilingual Kurdish narrators also contained a number of evaluative characteristics such as prosodic features, internal evaluation within the direct reported speech and the reporting clauses as indicated in Tables 4-6.

Table (4): Frequency of prosodic features

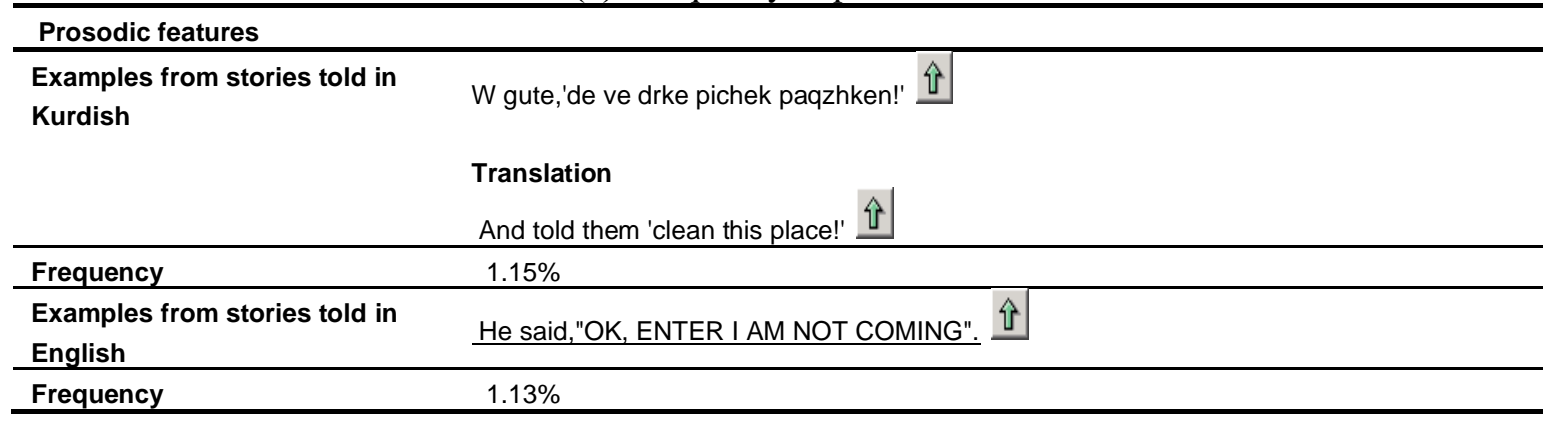

The comparison of the prosodic features summarized in Table 4 demonstrates their occurrence in the stories told in Kurdish and in English, indicating that this form of evaluation 
occurs slightly more frequently in the stories told in Kurdish than in the stories told in English $(1.15 \%$ and $1.13 \%)$ respectively. However, this was not the case for the second element of direct reported speech, where internal evaluation occurred within the reported clauses. While quantifying this element of direct reported speech in the stories told in Kurdish and in English, the following differences appear (see Table

Table (5): Frequency of internal evaluation within the reported clauses

\begin{tabular}{ll}
\hline Internal evaluation within the reported clauses \\
\hline $\begin{array}{l}\text { Examples from stories told in } \\
\text { Kurdish }\end{array}$ & $\begin{array}{l}\text { w gute,' eve chiy?' } \\
\text { Translation } \\
\text { And told them, 'what is this?' }\end{array}$ \\
\hline Frequency & $0.80 \%$ \\
\hline $\begin{array}{l}\text { Examples from stories told in } \\
\text { English }\end{array}$ & He said, 'Ok, do not go home, I am coming'. \\
\hline Frequency & $2.59 \%$ \\
\hline
\end{tabular}

Based on the results in Table 5, it appears that the frequency of the internal evaluation within the reported clauses in the stories told in English $(2.59 \%)$ is much higher than those told in Kurdish $(0.80 \%)$. This variance may be explained in relation to the quantitative results in (Table 2) of embedded evaluation in the stories told in Kurdish and in English. The earlier results showed a more frequent use of direct reported speech in the stories told in English than those in Kurdish. Based on these results, it might also be predicted that less instances of internal evaluation would be found within the direct reported speech in the stories told in Kurdish. Also this variance could be due to the subject matter of the stories told in Kurdish and in English, where the stories told in English tended to depict more dramatic episodes of interpersonal conflict between the protagonists. In addition to the variance in the occurrence of internal evaluation within the reported clauses, another variation is also coded for the reporting clauses in the stories told in Kurdish and in English (see Table 6).

Table (6): Frequency of reporting clauses

\begin{tabular}{ll}
\hline Reporting clauses & \\
\hline Examples from stories told in Kurdish & Guti,' b euroyekiya'. \\
& Translation \\
& He told her,' One euro'. \\
\hline Frequency & $2.04 \%$ \\
\hline Examples from stories told in English & $\begin{array}{l}\text { I told him, 'No- no. I told him to come because I } \\
\text { really wanted him to enjoy'. }\end{array}$ \\
\hline Frequency & $1.57 \%$ \\
\hline
\end{tabular}

The results in Table 6 suggest that both types of stories demonstrate a frequent use of reporting clauses, but they are more frequent in the stories told in Kurdish rather than those told in English $(2.04 \%$ and $1.57 \%)$ respectively. This result could be due to the fact that some of the reported speeches in the stories told in English are introduced by zero quotation formulas for example, and one of my desh-sister in law 'what happened?' After exploring the frequency of the elements found in the direct reported speech, it is necessary to further develop their importance in terms of evaluation.

Prosodic features have a significant role in dramatizing events. These features include loudness, intonation, pause, pace and so on. As suggested earlier, these resources can animate the protagonists in the story (Güthner, 1999: 704). The Kurdish speakers in the present data used loudness and intonation features while reporting their Arab teachers, employers and patients' utterances in order to create new characters, to give them new voices and better 
identify them to the listeners ( $\mathrm{Li}, 1986$ cited in Mason, 2008). Another relevant evaluative function of the prosodic features is seen as to reveal the narrators' stances towards the events in the story world (De Fina, 2006).

In addition, the combination of internal evaluative devices and reported speech also seems to give rise to increased involvement from the narrative audience, promoting moments where co-tellership becomes apparent. In the following example, the listener A's contributions occur immediately after the reported speech in line 18.

$18 \mathrm{M}$ : She always shows of like 'I am really/ I am Kurdish and I defend'.

19 A: patriot

$20 \mathrm{M}: \mathrm{hm}$

21 A: patriot

22 M: yea patriot

This dialogue is part of a story told by the narrator $M$ about her Arab teacher insulting Kurdish people in the class. The narrator $\mathrm{M}$ has used two internal evaluative devices (the lexical item 'really' and repetition) within her direct reported speech (line 18) to draw attention to an important situation depicting her classmate's pretence to defend her Kurdish self identification. The consequence of the evaluation clustering used by the narrator $\mathrm{M}$ was the involvement of the listener A. The listener A's involvement is categorized in her response repeating twice in lines 19 and 21 that the Kurdish narrator's classmate is a 'patriot'. The listener A's involvement conveys her moral stance towards the students behavior reinforcing the narrator M's evaluation. This involvement could be better explained in line with the idea of reported speech being 'dramatizing' the reported events (Labov, 1972 and Tannen, 2007) that implies the theatrical concept (Wierzbicka, 1974); where the actors address their audiences and attempt to involve them. Similarly the Kurdish narrators in my data, in particular, when they told stories in English have attempted to use various effective linguistic devices (internal evaluative devices) within their reported speech to involve the listeners in evaluating the acts of racism practiced by their Arab teachers, employers and patients.

The frequency of the embedded evaluation in the stories told in English suggests that the Kurdish speakers dramatize events more in their English stories rather than their Kurdish stories.
The reason for this could be explained in line with the different subject matter recounted in Kurdish and English stories. Most of the stories told in English were about the interpersonal ethnic challenges faced by the narrators, in particular, the racism acts practiced by Arabs against Kurds in different contexts. In contrast the stories told in Kurdish did not convey such challenges but recounted the social subject matters related to love, adventures, picnics and hostel life. A further reason could be the range of quotation verbs available, which is much wider in English than in Kurdish. In the English stories, the quotation verbs included, said, tell, ask, like, answer and call. In the Kurdish language only one reporting verb (gut), is used for both tell and say, and is used in these stories to introduce the reported speech. The reduced choices of the reporting verbs in Kurdish language might have limited the use of reported speech by Kurdish speakers in this data when telling stories in Kurdish. In addition to the dramatizing function of the reported speech, more investigation is required to understand the function of this form in terms of moral stance. Thus the function of reported speech to explore moral positioning is fully developed in the next section.

\subsubsection{Reported Speech and Moral Positioning}

To illustrate the wider role of reported speech in moral positioning, the analysis is focused on one narrative in particular told in English by the Kurdish speaker, Areen. She told her story in the presence of the interviewer, Talin and Jwan. In her story, Areen recites how her Arab teacher was insulting Kurds.

1. Areen Is it recording- is it recording

2. Talin Yea

3. Areen Alrghit I said "((aaaah))"

4. Well I was in a high school.

5. I never interfering anything.

6. I was never (.)

7. I was like silent.

8. And I was not doing anything.

9. I was doing my job, reading my exams, doing it that is it.

10. I was among= among Arabs that(.) time. 11. An-n-nd Not all Arabs. I mean(.) they- not $=$ they do not (.) like Kurds not all of them some

-some of them may be=may= be we have some rac...
12. Talin
Racist
13. Areen
Yea racist. 
14.

They are so racist.

15. I:::: was like seven years more then seven years among them and all $=$ evry.......

16. I was the top not praising myself,

17. but I was really the top.

18. and I got.

19. It was

20. And once (.) we were doing our exam (.) composition.

21. And-and (.) our math teacher she was visulating us.

22. And one of the students she ask a question.

23. And -and you know karama was full of Kurds at that time.

24. And she said "I know you Kurds y-you do not know anything, you=you even do not know how to express your selves in writing and stuff like that".

25. "You Kurds..." and she starts speaking about Kurdish people,

26. "You Kurds are like that. You Kurds".

27. I never ever said anything all my life infront of my teachers.

28. I was respecting them.

29. But that one really pissed me off.

30. An-n-nd suddenly while I was writing I said,"ALRIGHT MOM I AM A KURDISH. WHAT IS WRONG WITH ME? CAN'T I SPEAK? CANT I CONFRONT YOU? WELL I AM DOING MY EXAM, AND DOING GREAT REALLY, AND I AM THE TOP SO WHAT IS WRONG WITH ME?"

31. I shutted upa-n-nd she said, "Ok may be- be may be there are there are sometimes exceptions ye'ni'.
32. Jwan
Why?
33. Areen
I- I don't know.

34. I really got.......sh- sh- she pissed me off with that.

The moral stances projected through the evaluative reported speech in this story create a range of distancing effects between the narrator and the story protagonist. The way the narrator positions the Arab teacher in a derogatory way to Kurds in lines 24, 25 and 26 reveals the narrator's strong sense of disapproval towards the Arab teacher's words. The narrator distances herself from the Arab teacher's speech in two ways. First, the narrator clustered the reported speech with evaluative devices such as repetition, negation, the vocative you and the deictic that as it is obvious in Line 24 And she said "I know you Kurds y-you do not know anything, you=you even do not know how to express your selves in writing and stuff like that", line 25 "You Kurds..." and line 26 "You Kurds are like that. You Kurds". The repetition of the vocative you in lines 24, 25 and 26, depicts the impolite behavior and the pejorative superiority of the Arab teacher towards Kurds. Also the use of the deictic 'that' in line 26 instead of reciting the exact words of the Arab teacher suggests the offensive words of the Arab teacher towards Kurds. Second, the narrator, Areen distanced herself from the Arab teacher in lines 25 and 26 through the use of the zero quotation verbs. The instance of distancing portrayed in lines 24,25 and 26 implies the ethnical tensions between the Arabs and Kurds. Another feature of distancing is identified when the reported speech prompted external evaluation in lines 27, 28 and 29 "I never ever said anything all my life in front of my teachers", "I was respecting them" and "But that one really pissed me of". This instance of distancing indicates the narrator's strong sense of refusal towards the Arab teacher's action. A feature of distancing is also noticed in line 30 where the narrator quoted herself, I said, 'ALRIGHT MOM I AM A KURDISH. WHAT IS WRONG WITH ME? CAN'T I SPEAK? CANT I CONFRONT YOU? WELL I AM DOING MY EXAM, AND DOING GREAT REALLY, AND I AM THE TOP SO WHAT IS WRONG WITH ME?' In this example, the narrator addresses the Arab teacher defending her strong abilities of learning. The features of distancing employed here are the joint emphatic stress, questions and repetition. Another distancing feature is projected in line 31 she said, "Ok may be- be may be there are there are sometimes exceptions ye'ni" where the Arab teacher insisted to down grade Kurds as they know nothing and do not have the ability to learn and if there are any, they will be possibly few. This distancing is expressed by the internal evaluation of repetition that is clustered with the reported speech. Another feature of distancing is identified through the co-tellership followed the reported speech in line 32 "why" where the interlocutor Jwan was asking why the Arab teacher behaves in this way. This coconstruction shows that Kurds share the same values that Arabs are racist.

To sum up, reported speech clustered with other evaluative devices help identifying a range of moral positioning towards the events. In turn, the varying moral positioning identified in this 
narrative proposed two different types of identities: the racist identity of the Arab teacher and the patriotic and respectful identity of the Kurdish narrator.

\section{CONCLUSION}

In this study it has been shown how the quantitative analysis of Labovian (1972) evaluative devices have provided the start point to identify the moral positioning by Kurdish bilingual speakers. The moral positioning in this article promoted a range of distancing between the protagonists. The distancing identified was Kurdish -Arabic. This distancing indicated the racial tension between Kurds and Arabs that is resulted from the Arab teacher's interactions with the Kurdish students, depicting them in an insulting way, i.e, nominating their ethnic identity and evaluating this negatively. The distancing between the protagonists is achieved by a range of evaluative devices, such as: direct reported speech clustered with the internal evaluative devices, prosodic features, voice quality, co-construction features, and external evaluation.

\section{LIMITATION OF THE STUDY}

As this was a very simple attempt towards exploring the Kurdish self- representations and identities, this study was limited to a few numbers of Kurdish participants only. The crosscultural analysis was conducted by comparing the Kurdish and English stories told by the Kurdish participants as it was very hard for the researcher to recruit native English participants of English who spoke Kurdish as their second language. Moreover, the researcher did not take gender as a variable in the current study. In the future research, these limitations could be overcome and the upcoming studies might include larger number of participants, recruit native English participants and take gender as a variable for the analysis. This will help drawing more general and richer conclusions concerning the Kurdish narrators' cultural and social identities.

\section{BIBLIOGRAPHY}

Balatay, A., 2014. What do Arab want from Kurdistan.
http://www.hekar.net/modules.php?name=Ne $\underline{\text { ws } \& \text { file }=\text { article } \& \text { sid }=17801}$.

Cortazzi, M. \& Jin, L., 1999. Evaluating Evaluation in narrative. In Hunsron, S. \& Thompson, G., eds, narrative in Evaluation in text: authorial stance and the construction of discourse. New York: Oxford University press.

Couper Kuhlen, E. (1986). An introduction to English prosody. London: Edward Arnold.

De Fina, A. (2006). Group identity, narrative and self- representations. In: De Fina, A. Schiffrin, D. \& Bamberg, M. (eds), Discourse and identity. Cambridge: Cambridge University Press, pp. 351-375.

Georgakopoulou, A., 2005. Same old story? On the interactional dynamics of shared narratives. In Quasthoff, U. \& Becker, T., eds,. Narrative interaction. Amsterdam/Philadelphia: John Benjamins

Georgakopoulou, A. (2007). Small stories, interaction and identities. Amsterdam: John Benjamins Pub.

Güthner, S. (1999). Polyphony and the 'layering of voices' in reported dialogues: an analysis of the use of prosodic devices in every day reported speech. Journal of Pragmatics, 31, pp. 685-708.

Jen-Chang, M., 2008. A cross- cultural study of Taiwanese and British University students' oral narratives. PhD Thesis. University of Leicester.

Johnstone, D., 2001. Discourse analysis and narrative. In Schiffrin, D.E., ed, The handbook of discourse analysis . Oxford: Blackwell.

Klapproth, M., 2004. Narrative as social practice: Anglo- Western and Australian Aboriginal oral traditions. NewYork: Mouton De Gruyter.

Labov, W. (1972). Language in the inner city: studies in the Black English vernacular. Philadelphia: The University of Pennsylvania Press.

Labov, W. \& Waletsky, J. (1967). Narrative analysis: oral versions of personal experience. In: Helm,J., ed, Essays on the verbal and visual arts: proceedings of the 1966 annual spring meeting of the American ethnological society. Seattle: University of Washington Press, pp. 12-44. 
Levey, S. (2003). Reported dialogue and pragmatic particles in the narratives of preadolescents. World Englishes, 22(3), pp. 305-321.

Lucy, John A. (ed). (1993). Reflexive language: reported speech and metapragmatics. Cambridge: Cambridge University Press.

Mason, R. (2008). The use of evaluative devices in the narrative discourse of young second language learners. Dallas: SIL International. Available

from:

www.sil.org/silepubs/abstract.asp? $=92847459$ 264[Accessed April 1012].

Norrick, N., 2000. Conversational narrative: Storytelling in every day talk. Amsterdam/Philadelphia: John Benjamins.

Ochs, E. \& Capps, L. (2001). Living narrative: creating lives in every day storytelling. Cambridge: Mass: Harvard University press.

Jr. Oliveira, M \& Cunha, D (2004). Prosody as marker of direct reported speech boundary. ResearchGate. https://www.researchgate.net/publication/2354 07120.

Pastor, R. \& Maria, A. (2004). Living in a second language: self-representation in reported dialogues of Latinas' narratives of personal language experience. Applied Linguistics, 2(14), pp. 91-114.

Patton, M. (2002). Qualitative research and evaluation methods. London: Thousand Oaks, Calif.

Patterson, W., 2008. Narratives of events: Labovian narratives analysis and its limitations. In Andrews, M., et al. ed,. Doing narrative research. London: Sage.
Peterson, C. \& McCabe, A., 1983. Developmental psycholinguistics: Three ways of looking at child's narrative. New York: Plenum Press.

Polanyi, L.(1985). Telling the American story: a structural and cultural analysis of conversational storytelling. Norwood: NJ:Ablex.

Smith, J., 2006. Narrative sociolinguistic research. United Kingdom: Elsevier.

Sunakawa, Y., 2010. Manipulation of voices in the development of a story: prosody and voice quality of Japanese direct reported speech. In Szatrowski, P. E., Storytelling across Japanese conversational genre. Amsterdam. John Benjamin

Tannen, D. (2007). Talking voices: repetition, dialogue, and imagery in conversational discourse. 2 edn. Cambridge: Cambridge University Press.

Toolan, M.J. (1988). Narrative: a critical linguistic introduction. London and New York: Routledge.

Hamo,B.\&Aadullah,J.,2014. تقييم النزاع في مدينة دهوك: دراسة ميدانية عن وضع النازحين العرب في المدينة Translation: A field research on the Arab imigrants in Duhok city: Assessing the conflict).

Voloshinov, V. (1973). Marxism and the philosophy of language. L. Matejka \& I. Titunik (Trans.). Cambridge: MA: Harvard University Press.

Wanger, p; Malisz, z; and Kopp, S. (2014) Gesture and speech in interaction: An overview. Speeech Communication , (57) 209-232.

Wierzbicka, A. (1974). The semantics of direct and indirect discourse papers in linguistics. Papers in Linguistics, 7(3-4), pp. 267-307. 


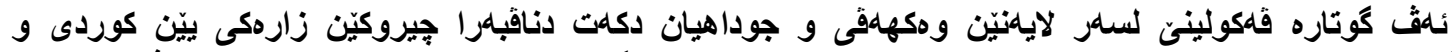

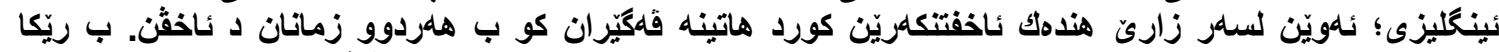

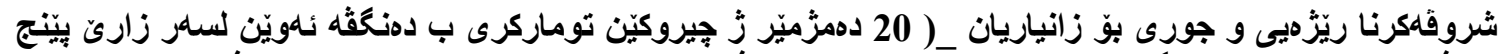

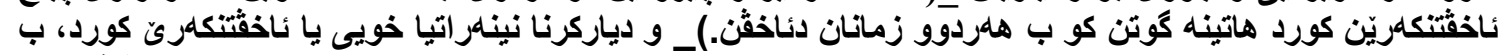

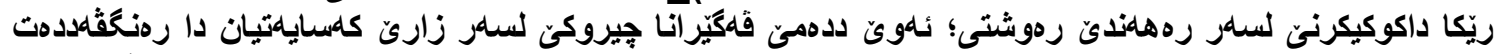

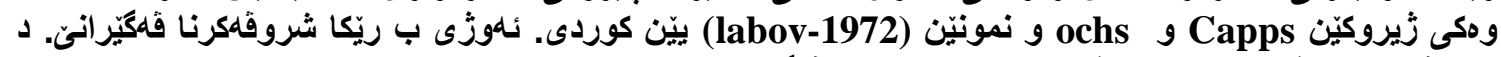

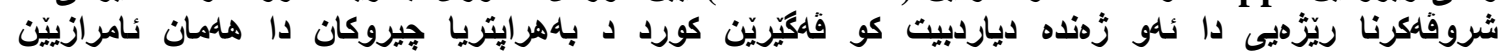

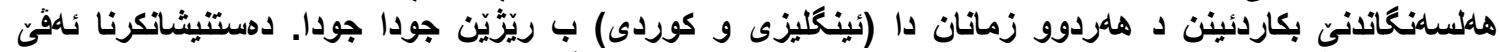

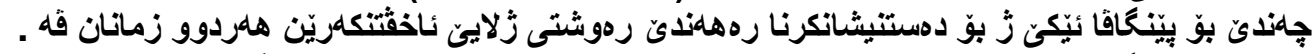

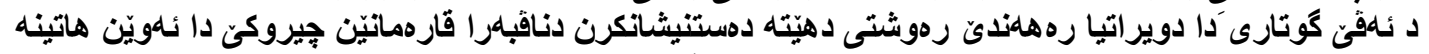

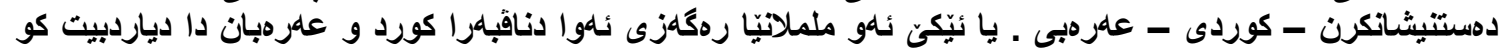

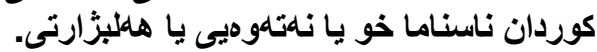

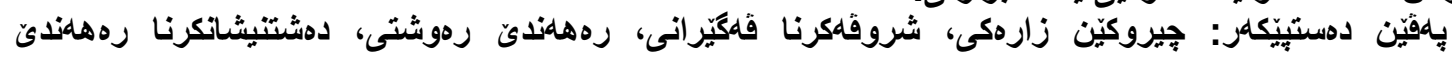
روشتى.

الخلاصة

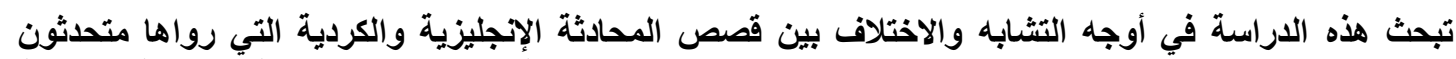

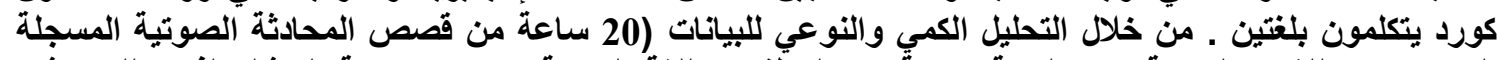

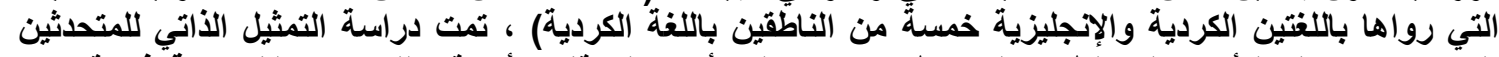

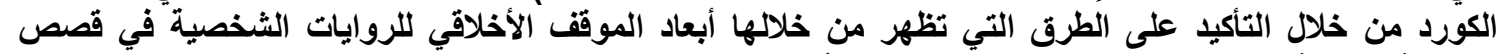

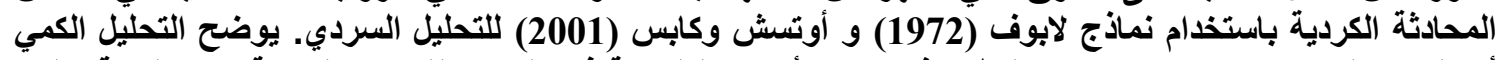

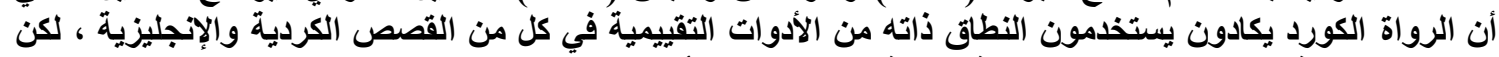

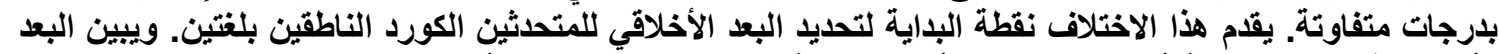

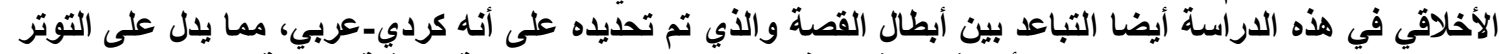

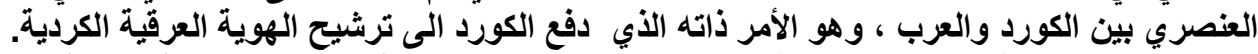

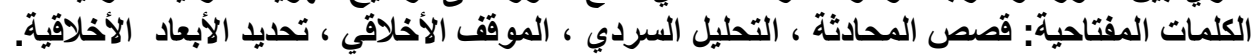

